\title{
IDENTIFIKASI KEMAMPUAN KERJA APARAT DAN PENGARUHNYA TERHADAP KUALITAS PELAYANAN PUBLIK (Studi Kasus di Kecamatan Abeli Kota Kendari)
}

\author{
Oleh: \\ Muhammad Yusuf ${ }^{1}$, Wempi Banga ${ }^{2}$ \\ 1,2 Dosen Jurusan Ilmu Administrasi Publik Universitas Halu Oleo \\ muh.yusuf@uho.ac.id
}

\begin{abstract}
The purpose of this study is expected to be useful for the development of the concept of quality public services in order to develop lecture material in the field of public administration, and also useful as a contribution of thought to the local government of Kendari City in the form of community service.

The population in this study were 203 people, consisting of elements from the village and sub-district government officials and community elements who had received custody services in the last three months (April, May and June 2009). The sample size is calculated according to Yamne formula, by setting a precision of 5\% and a degree of trust of 95\%, then the sample obtained by respondents is 158 people. The sampling of each element is based on a proportional formula then drawn by a simple random sampling technique from each element. Data collection / information, breastfeeding using questionnaires and interviews. Data analysis was performed using tabulation tools, percentages and averages, which were then interpreted to determine the level of influence of variable dimensions of the apparatus' ability on the variable quality of public services in the Abeli District of Kendari City.

The results of this study indicate that the condition of the ability of government officials to work in public services in the Abeli District of Kendari City can be illustrated through 3 (three) basic dimensions of apparatus capacity, as follows: (b) Professional technical training possessed by apparatus is classified as high. (c) The work experience of the officers in general is less useful because their placement is not relevant to their work experience. With these conditions, the influence of the ability of government officials on the quality of public services in the Abeli District of Kendari City is generally low.
\end{abstract}

\section{Keywords: Apparatus Ability, Quality of Public Services}

\section{PENDAHULUAN}

Isu pelayanan publik yang berkualitas merupakan salah satu isu sentral dalam konteks ilmu administrasi negara. Terlebih setelah memasuki era reformasi administrasi, yakni sejak tumbangnya rezim orde baru pada tahun 1996 yang lalu. Salah satu fakta administrasi yang sangat menonjol dilihat dari sisi reformasi administrsi Negara, adalah pergeseran kamauan politik pemerintah bersama DPR yaitu bergeser dari pemikiran yang cenderung sentralistik dan otoriterian, menjadi pemikiran yang desentralistik dan demoktratis.

Llahirnya Undang-Undang Nomor 22 Tahun 1999 tentang Pemerintahan Daerah yang telah diesempurnakan/ diperbaharaui dengan Undang-Undang Nomor 32 Tahun 2004. Salah satu tujuan yang ingin diwujudkan melalui undang-undang itu, adalah dalam rangka perbaikan dan peningkatan kualitas pelayanan publik bagi masyarakat yang ada di daerah. Kebijakan otonomi daerah pada dasarnya merupakan kemauan politik pemerintah bersama DPR untuk lebih mendekatkan pelayanan bagi masyarakat yang ada di daerah, terutama 
Vol.2 No.1. April 2018. pp.38-50.Copyright@2018 PUBLICUHO Faculty of Social and Political Sciences Halu Oleo University, Kendari, Southeast Sulawesi, Indonesia.e-ISSN: 2621-1351. Open Access at:

http://ojs.uho.ac.id/index.php/PUBLICUHO

Jounal publiuho is licensed under a Creative Commons Attribution 4.0 International License, which permits unrestricted use, distribution, and reproduction in any medium, provided the original work is properly cited.

bagi masyarakat yang berada di daerah-daerah terpencil. Dengan pelayanan yang semakin dekat pada publik itu, diharapkan mampu meningkatkan kesejahteraan masyarakat di daerah. Harapannya adalah pada wilayah administratif yang lebih kecil di kecamatan dan keluarahan/desa dapat merasakan pembangunan berupa pelayanan publik yang adil dan merata di semua titik atau simpul masyarakat.

Berkaitan dengan kualitas pelayanan publik yang dikemukakan tersebut, maka kualitas pelayanan publik dapat diidentifikasi melalui rumusan kualitas pelayanan yang dikemukakan oleh Parasuraman (1990:36) sebagai kemampuan memperpendek jarak antara pelayanan yang diharapkan (expected service) dengan pelayanan yang diterima atau dirasakan (perceived service). Jika pelayanan yang diterima sama dengan pelayanan yang diharapkan maka kualitas pelayanan publik dapat diidentifikasi sebagai mutu pelayanan yang baik. Bila pelayanan yang diterima melebihi apa yang diharapkan, diidentifikasi sebagai kualitas ideal. Sedangkan pelayanan yang diterima lebih rendah daripda apa yang diharapkan, maka mutu pelayanan diidentifikasi sebagai mutu pelayanan yang buruk.

Pelayanan publik di Kecamatan Abeli Kota Kendari, menunjukkan adanya masalah yang perlu mendapat perhatian karena belum sesuai dengan harapan masayarakat. Fenomena menunjukkan bahwa pelayanan publik di tingkat kecamatan yang dilakukan oleh aparat kecamatan, masih memperlihatkan pola pelayanan yang lamban, menunda-nunda waktu, kurang disiplin dalam pelayanan, tidak adanya standar biaya dan waktu pelayanan serta belum tranparan (Wawancara dengan tokoh masyarakat setempat, tanggal 2 Juni 2009).

Fenomena ini ditunjukkan melalui pelayanan dalam bentuk pengurusan administrasi yang dikeluarkan oleh Lurah/Kepala Desa di wilayah Kecamatan Abeli, ternyata masih menunjukkan pola-pola lama. Seperti yang disampaikan oleh salah satu warga berikut:

"pengurusan surat keterangan IMB, yang dikeluarkan oleh Lurah dan harus diketahui oleh Camat, surat akte jual beli yang harus dikeluarkan oleh lurah dan ditandatangai oleh Camat, surat kartu tanda penduduk (KTP), kartu keluarga, masih cenderung mengecewakan. Hal ini disebabkan karena tidak adanya kepastian waktu pelayanan/kepastian selesainya urusan, sering tertunda-tunda, tidak transparannya tarif pembayaran dan sebagainya (Wawancara tanggal, 4 Juni 2009).

Fakta ini diduga dipengaruhi oleh masih kurangnya kemampuan aparat pemerintah yang melaksanakan tugas pelayanan publik di tingkat kelurahan maupun di tingkat kecamatan dalam wilayah Kecamatan Abeli Kota Kendari. Data menunjukkan bahwa jumlah aparat pemerintah di tingkat kecamatan sebanyak 16 orang, dengan tingkat pendidikan formal : (31,25\% S-1 dan selebihnya 68,75 \% tamat SMA dsn SMP). Aparat Kecamatan Abeli yang pernah mengikuti diklat teknis profesional baru sebanyak 25\% (75\% belum pernah mengkuti diklat teknis professional). Sedangkan di tingkat Kelurahan, jumlah aparat yang terlibat dalam tugas pelayanan publik sebanyak 91 orang, dengan tingkat pendidikan formal: (43\% S-l dan selebihnya atau 57\% tamat SMA dsn SMP). Aparat kelurahan yang pernah mengikuti diklat teknis profesional hanya $43 \%$ (57\% belum pernah ikut diklat), sehingga menjadi alasan pentingnya dilakukan penelitian guna mencari upaya pemecahan masalah agar pelayanan publik yang prima yaitu pelayanan yang dapat memuaskan masyarakat, dapat diwujudkan di wilayah Kecamatan Abeli Kota Kendari. Jika hal ini tidak segera mendapat perhatian oleh semua pihak, maka harapan yang ingin dicapai dalam implementasi kebijakan otonomi daerah, akan semakin jauh dari harapan.

\section{TINJAUAAN PUSTAKA}

\section{Konsep Kemampuan Aparat}

Kemampuan aparat adalah merupakan suatu konsep dalam ilmu administrasi, khususnya dalam kajian teori organsasi dan manajemen sumber daya manusia. Berbagai rumusan tentang kemampuan aparat yang dikemukakan oleh para pakar, namun pada prinsipnya dipertegas oleh Hasibuan (2000:12) bahwa kemampuan aparat adalah totalitas dari semua keahlian yang diperlukan untuk mencapai hasil kerja yang bisa 
dipertanggungjawabkan. Pada bagian lain, konsep kemampuan aparat lebih diperjelas oleh Hasibuan (2000:13) bahwa :Kemampuan adalah kumpulan pengetahuan yang diperlukan untuk: (1) melaksanakan prosedur kerja yang praktis, teknis-teknis khusus yang berkaitan dengan disiplin ilmu pengetahuan; (2) menyelaraskan bermcam-macam elemen yang semuanya terlibat dalam penyusunan kebijakan dan dalam situasi manajemen; (3) kemampuan mengkombinasikan elemen-elemen dari perenanaan, pengorganisasian, pengaturan, penilaian dan pembaharuan; (4) kemampuan dapat memberikan motivasi kerja secara langsung. Menjadi jelas bahwa kemampuan itu melekat pada diri individu yang dapat terbentuk melalui proses kehidupannya, misalnya melalui proses pembelajaran (lerning process). Oleh karena itu, Bernaddin (1995:33) berpendapat bahwa kemampuan pada dasarnya merupakan sumber daya yang dimiliki oleh seseorang yang memberi kemungkinan untuk melakukan suatu tugs atau pekerjaan dengan baik.

Terkait dengan aparat pemerintah, Notoatmodjo (1998:24) menyatakan bahwa bagimanapun canggihnya sarana dan prasarana organisasi pemerintahan tanpa ditunjang oleh kemampuan aparat, niscaya organisasi itu tidak akan mampu menjalankan tugas dan fungsinya dengan baik. Terkait dengan kemampuan kerja aparat pemerintah, Rasyid (1997:128) berpendapat bahwa :

"Dalam praktek pemerintahan dibutuhkan kualitas kepegawaian yang berkenaan dengan skill yang menyangkut kemampuan kerja untuk secara tepat memahami masalah dan tantangan yang secara nyata dihadapi, mengembangkan berbagai pilihan preskripsi dalam upaya memecahkan masalah dan menjawab tantangan itu, serta membangun dukngan yang luas dalam mencapai misi organisasi. Jadi kemampuan aparat adalah segala kemampuan atau daya dan potensi yang dimiliki oleh aparat pemerintah atau pegawai negeri, abdi masyarakat, dalam menjalankan tugas dan fungsinya."

\section{Dimensi-Dimensi Kemampuan Kerja}

Kemampuan kerja sebagai suatu variabel dalam penelitaian ini, mempunyai beberapa dimensi. Setiap dimensi mempunyai kedudukan dan peranan yang sama-sama membentuk kemampuan kerja seorang aparat atau seorang pegawai. Kemapuan tersebut merupakan prasyarat dalam melakukan rekruitmen dan promosi pegawai dalam suatu organisasi.

Sjahrir (1986:32) memperjelas bahwa kemampuan aparat adalah potensi sumber daya aparat yang mencakup 4 (empat) dimensi, yaitu: (a) pengetahuan yang diperoleh melalui pendidikan formal, (b) ketrampilan yang diperolrh melalui diklat teknis profesional, (c) pengalaman kerja, dan (d) kerja sama antara sesama personil, antara unit dalam organisasi dan antara organisasi dengan masyarakat. Baik buruknya suatu pelayanan publik, sangat tergantung pada kemampuan yang dimiliki oleh aparat. Lebih lanjut dijelaskan oleh Syafiie (1999:23) bahwa seseorang memiliki pengetahuan yang diperolehnya melalui sistem pendidikan mulai dari Sekolah Dasar sampai ke jenjang pendidikan tinggi, sedangkan ketrampilan diperoleh melalui latihan atau praktek. Hal yang sama dikemukakan oleh Siagian (1997:175) bahwa pendidikan adalah keseluruhan proses, teknik dan metode belajar mengajar dalam rangka mengalihkan suatu pengetahuan dari seseorang kepada orang lain sesuai dengan standar tertentu. Demikian pula latihan merupakan proses belajar mengajar dengan menggunakan metode dan teknik tertentu, yang penekanannya pada ketrampilan untuk meningkatkan kemampuan kerja pada jenis keperjaan atau tugas tertentu. Biasanya, sasaran latihan adalah seseorang atau kelompok yang sudah bekerja pada suatu organisasi tertentu.

\section{Konsep Pelayanan Publik}

Pelayanan publik adalah merupakan isu sentral dalam ilmu administarasi Negara. Hal ini merupakan tugas dan fungsi pokok dari aparat pemerintah, yang dimanifestasikan melalui fungsi birokrasi pemerintahan. Berbagai pandangan teoretis yang dikemukakan oleh pada pakar dalam bidang ilmu administrasi Negara tentang konsep pelayanan publik. Dikaitkan dengan fungsi pemerintah sebagai pelayan publik, oleh Rasyid 
Vol.2 No.1. April 2018. pp.38-50.Copyright@2018 PUBLICUHO Faculty of Social and Political Sciences Halu Oleo University, Kendari, Southeast Sulawesi, Indonesia.e-ISSN: 2621-1351. Open Access at:

http://ojs.uho.ac.id/index.php/PUBLICUHO

CC (P) Jounal publiuho is licensed under a Creative Commons Attribution 4.0 International License, which permits unrestricted use, distribution, and reproduction in any medium, provided the original work is properly cited.

(1997:116) menegaskan bahwa pelayanan publik berkenan dengan usaha pemerintah yang bertujuan untuk menciptakan kondisi yang menjamin bahwa warga masyarakat dapat menjalani kehidupannya secara wajar, dan ditujukan juga untuk membangun dan memelihara keadilan dalam masyarakat. Kemudian Simbolon (1998:9) mempertegas dengan memberikan 3 (tiga) unsur pelayanan organisasi yang baik, yaitu: (1) susunan strategi pelayanan yang baik; (2) orang-orang di level operasional harus memiliki orientasi yang tinggi terhadap pelanggan; (3) sistem pelayanan yang tidak menyulitkan pelanggan.

Dari pandangan tersebut, paling tidak terdapat 3 (tiga) faktor yang penting mendapat perhatian dalam konsep pelayanan publik : (1) Faktor manusia yang melaksanakan pelayanan itu; (2) adanya prosedur dan standar yang tetap; (3) ketaatan dan kedisiplinan terhadap prosedur.

\section{Pengukuran Kualitas Pelayanan Publik}

Kualitas pelayanan publik menjadi sangat penting, karena terkait dengan kepuasan pihak yang dilayani. Dengan kata lain, kualitas pelayanan publik menjadi sorotan dunia pelanggan atau sorotan pihak publik yang menerima pelayanan aparat pemerintah. Oleh karena itu, sudah menjadi trend dalam dunia modern saat ini bahwa pelayaan publik tidak sekedar formalitas, tetapi lebih mengarah kepada pelayanan publik yang kompetitif.

Pengukuran kualitas pelayanan publik menurut Tjiptono (1996:54) adalah diukur dari aspek kepuasan masyarakat atau kepuasan pelanggan. Selanjutnya menurut Moenir (1995:197) untuk dapat memberi kualitas pelayanan yang memuaskan maka ada empat aspek pelayanan pokok yang harus dipenuhi yaitu: (l) Tingkah laku yang sopan; (2) Cara penyampaian tentang sesuatu yang akan diterima oleh orang yang dilayani; (3) Waktu penyampaian yang tepat; (4) Keramahtamahan.

Selanjutnya, dari sisi kualitas pelayanan yang diharapkan oleh masyarakat sebagai pihak yang dilayani, menurut Sumarjono (1989:15) dijelaskan bahwa bagi anggota masyarakat, kualitas pelayanan publik diukur dari beberapa dimensi yaitu : (1) Ketepatan waktu pelayanan; (2) Jaminan terhadap hasil layanan; (3) Perhatian terhadap masyarakat melalui komunikasi yang hangat sebagai wujud empati; (4) Tarif pelayanan yang memadai atau terjangkau oleh seluruh komponen masyarakat; (5) Kecepatan pelayanan; (6) Bersikap adil dalam melakukan pelayanan; (7) Alat penunjang yang cukup sesuai dengan kebutuhan pelayanan.

Pada akhirnya dapat dirangkum bahwa kualtas pelayanan itu sendiri dicirikan oleh tumbuh dan tercapainya kepuasan serta citra yang positif dari masyarakat, baik terhadap individu aparat pemerintah yang bertugas melayani, maupun terhadap unit-unit pelayanan dan secara umum instansi pemerintah.

\section{KERANGKA PEMIKIRAN}

Sebagai dudukan hubungan variabel dalam penelitian ini, secara teoretis dikemukakan oleh Syahrir (1986:32) bahwa baik buruknya suatu pelayanan publik, sangat tergantung pada kemampuan yang dimiliki oleh aparat yang malayani. Lebih dipertegas oleh Notoatmodjo (1996:24) bahwa bagimanapun canggihnya sarana dan prasarana organisasi pemerintahan tanpa ditunjang oleh kemampuan aparat, maka organisasi itu tidak akan mampu menjalankan tugas dan fungsinya dengan baik. Demikian pula menurut Hasibuan (2000:12) bahwa kemampuan aparat adalah totalitas dari semua keahlian yang diperlukan untuk mencapai hasil kerja yang bisa dipertanggungjawabkan.

Selanjutnya, untuk variabel kemampuan kerja aparat, penulis mengacu kepada 3 (tiga) dimensi utama dari variabel kemampuan aparat yang dikemukakan oleh Sjahrir (1986:32) yaitu: (a) pendidikan formal, (b) diklat teknis profesional, (c) pengalaman kerja. Sedangkan untuk variabel kualitas pelayanan, penulis mengacu kepada teori yang dikemukakan oleh Sumarjono (1989:15) bahwa dari sisi kepentingan masyarakat, kualitas pelayanan publik diukur dari 6 (enam) dimensi yaitu: (1) Ketepatan waktu pelayanan; (2) Perhatian terhadap masyarakat melalui komunikasi yang hangat sebagai wujud empati; (3) Tarif pelayanan yang memadai atau 
terjangkau oleh seluruh komponen masyarakat; (4) Kecepatan pelayanan; (5) Bersikap adil dalam melakukan pelayanan; (6) Alat penunjang yang cukup sesuai dengan kebutuhan pelayanan.

Untuk memperjelas alur pemikiran dalam peneltian ini, penulis kemukakan hubungan variabel kemampuan kerja aparat dengan variabel kualitas pelayanan publik melalui gambar berikut :

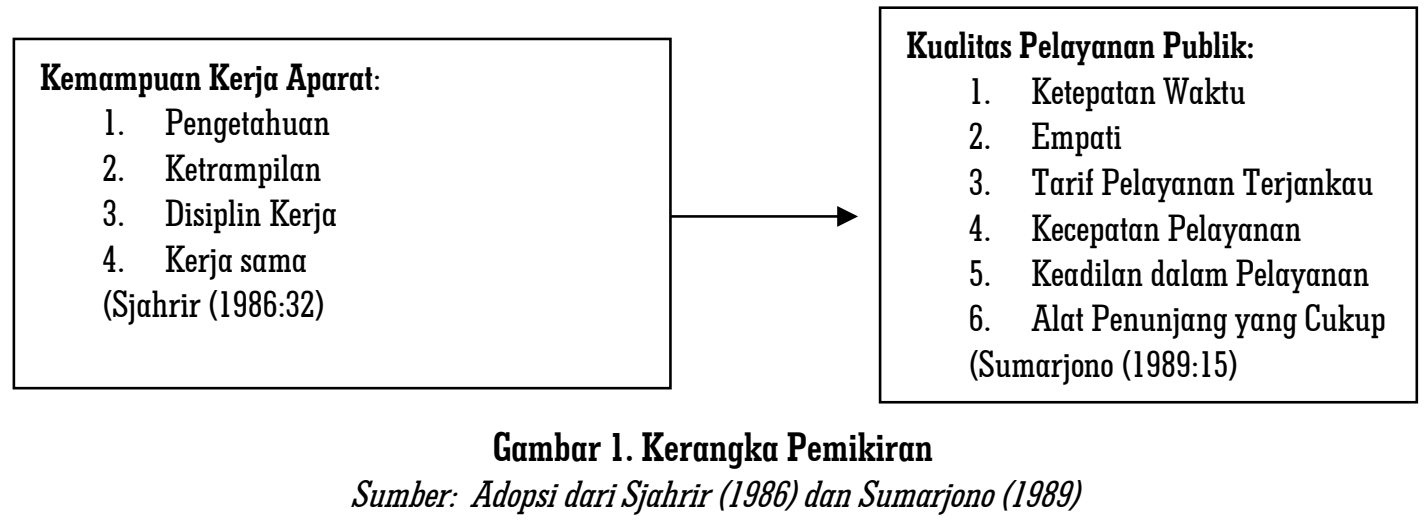

\section{METODE PENELITIANN}

Penelitian ini dilaksanakan di Kecamatan Abeli Kota Kendari. Populasi dalam penelitian ini terdiri dari unsur aparat pemerintah sebagai pihak yang melayani dan unsur masyarakat sebagai pihak yang dilayani. Populasi unsur aparat adalah suluruh aparat pemerintah pada kantor kecamatan Abeli dan seluruh aparat pemerintah pada 13 kantor kelurahan di Kecamatan Abeli, yang jumlahnya sebanyak 107 orang. Sedangkan populasi unsur masyarakat adalah seluruh anggota masyarakat di Kecamatan Abeli yang pernah mendapat pelayanan dari aparat pemerintah baik pada kantor kecamatan maupun pada kantor kelurahan di wilayah kecamatan Abeli dalam tiga tahun terakhir (April, Mei, dan Juni 2009), yang jumlahnya sebanyak 156 orang. Dengan demikian jumlah populasi seluruhnya adalah sebanyak 263 orang.

Selanjutnya ukuran sample penelitian ditetapkan dengan menggunakan rumus dari Yamane dalam Rahkmat (1993:82) sebagai berikut:

$$
\mathrm{n}=\mathrm{N}
$$

Dengan rumus tersebut, selanjutnya ditetapkan presisi sebesar 5\% dengan tingkat kepercayaan $95 \%$ maka jumlah sampel sebagai berikut:

$$
\mathrm{Nn}=
$$

$(263)(0,05)^{2}+1 \quad 1.6575$

Selanjutnya akan ditarik dengan menggunakan rumus proporsional dari Nasir di bawah ini:

$$
\mathrm{ni}=\stackrel{\mathrm{Ni}}{\mathrm{N}} \text { (Nasir, 1989:365) }
$$

Dengan rumus yang digunakan itu maka diperoleh sample masing unsur populasi sebagai berikut:

1. Unsur aparat kecamatan $=16$

$263 \quad 158=10$ orang

2. Unsur aparat kelurahan $=91$ 


$$
\text { ------- x } 158=55 \text { orang }
$$

263

3. Unsur masyarakat yang penah menerima pelayanan dalam tiga bulan terakhir sebanyak 156

263

Selanjutnya dilakukan penentuan sampel dari masing unsur populasi dengan menggunakan teknik simple random samping. Selanjutnya untuk data yang terkumpul dianalisis dengan menggunakan tabulasi silang dan persentase, kemudian diberi interpretasi untuk menjelaskan hubungan pengaruh antara variabel kemampuan aparat pemerintah dengan variabel kualitas pelayanan publik.

\section{PEMBAHASAN}

\section{Kondisi Kemampuan Aparat Dalam Pelaksanaan Tugas dan Fungsinya Sebagai Pelayan Publik di Kecamatan Ảbeli Kota Kendari}

Dalam penelitian ini variabel kemampuan aparat (independen varieble) dilihat dari 3 (tiga) dimensi berupa: (l) pendidikan formal; (2) Diklat teknis profesional; (3) Pengalaman kerja; Ketiga dimensi tersebut diteliti pengaruhnya terhadap kualitas pelayanan publik di Kecamatan Abeli Kota Kendari. Sedangkan variabel kualitas pelayanan publik (dependen variable) dilihat dari 6 dimensi yang mencakup: (1) Ketepatan Waktu; (2) Empati; (3) Tarif Pelayanan Terjangkau; (4)Kecepatan Pelayanan; (5) Keadilan dalam Pelayanan; (6)Alat Penunjang yang Cukup.

Hasil penelitian tentang pengaruh variabel kemampuan aparat yang dilihat dari 3 (tiga) dimensi tersebut terhadap kualitas pelayanan publik di Kecamatan Abeli, diawali dengan kondisi tingkat pendidikan formal aparat yang dapat dilihat melalui sajian tabel 1 berikut ini.

Tabel 1

Kondisi Tingkat Pendidikan Formal Aparat Pemerintah

Di Kecamatan Abeli Kota Kendari, Tahun 2009

\begin{tabular}{|c|c|c|c|}
\hline No. & Tingkat Pendidikan & Frekuensi (F) & Persentase (\%) \\
\hline 01 & S-2 & 7 & 10,77 \\
\hline 02 & S-l & 12 & 18,46 \\
\hline 03 & Sarmud/Sederajat & 6 & 9,24 \\
\hline 04 & SMA/Sederajat & 36 & 55,38 \\
\hline 05 & SMP ke bawah & 4 & 6,15 \\
\hline & Jumlah & 65 & 100 \\
\hline
\end{tabular}

Sumber : Diolah Hasil Penelitian, 2009.

Pada tabel 1 menunjukkan bahwa tingkat pendidikan aparat pemerintah di Kecamatan Abeli Kota Kendari masih relatif tegolong rendah, dilihat dari komposisi tingkat pendidikan aparat di daerah itu. Terlihat bahwa yang berpendidikan minimal S-l ke atas, hanya berkisar $19 \%$. Sedangkan tingkat pendidikan aparat pemerintah yang S-l ke atas untuk rata-rata nasional, adalah 35 sampai 40\%. Hal ini penting mendapat perhatian oleh pihak pemerintah Kota Kendari mengingat berbagai pandangan teoretis yang ditekankan oleh para ahli tentang pentinnya pendidikan formal dalam meningkatkan kemampuan sumber daya manusia (Syafiie,1999:23). Terkait hasil wawancara penulis dengan salah seorang informan menjelaskan bahwa: 
Terbatasnya jumlah pegawai yang mengikuti pendidikan lanjutan di berbagai perguruan tinggi, baik pada jenjang S-l maupun pada jenjang S-2, antara lain disebabkan oleh dua hal. Pertama, pengalaman menunjukkan bahwa pegawai yang telah selesai mengikuti pendidikan lanjutan sampai ke jenjang S-2, ternyata tidak mendapat perhatian dalam bentuk reword pimpipinan kepada mereka yang telah berasil meningkatkan pendidikannya. Kedua, masih sangat terbatas anggaran yang diesdiakan oleh pemerintah daerah guna membantu biaya pendidikan bagi aparat yang melanjutkan pendidikan formal (wawancara tgl. 5 November 2009).

Berkaitan dengan uraian di atas, Siagian (1997:175) mengemukakan konsep teoretis yang menjelaskan bahwa tingkat pendidikan formal merupakan salah satu indikator yang menentukan kemampuan sumber daya manusia dalam suatu organisasi. Setelah dilakukan penelitian lapangan guna mengetahui pandangan responden tentang penomena yang terkait dengan pandangan teoretis tersebut, maka diperoleh hasil kajian lapangan yang menunjukkan pandangan responden tentang manfaat pendidikan formal dalam menunjang kemampuan kerja aparat. Sebelum disajikan data tentang pandangan responden mengenai manfaat pendidikan formal dalam menunjang kemampuan kerja pegawai maka berikut ini disajikan data hasil penelitian tentang keikutsertaan responden dalam mengikuti pendidikan informal berupa pendidikan dan pelatihan (diklat) sebagaimana diperlihatkan melalui tabel 2 di bawah ini:

\section{Tabel 2}

Keikutsertaan Dalam Pendidikan dan Pelatihan Oleh Aparat Pemerintah di Kecamatan Abeli Kota Kendari (Keadaan Tahun.2009)

\begin{tabular}{|c|c|c|c|}
\hline No. & Kategori & Frekuensi (F) & Persentase (\%) \\
\hline 01 & 7 kali atau lebih & 0 & 00,00 \\
\hline 02 & 5 sampai 6 kali & 6 & 09,23 \\
\hline 03 & 3 sampai 4 kali & 12 & 18,46 \\
\hline 04 & l sampai 2 kali & 36 & 55,39 \\
\hline 05 & Belum pernah & 11 & 16,92 \\
\hline \multicolumn{2}{|r|}{ Jumlah } & 65 & 100,00 \\
\hline
\end{tabular}

Sumber : Diolah Hasil Penelitian, 2009.

Pada tabel 2, jumlah aparat di Kecamatan Abeli yang telah mengikuti diklat sebanyapat k 83,08\%, di antaranya terdapat $9,23 \%$ telah mengikuti diklat antara 5 sampai enam kali. Dengan demikian sisa $16,92 \%$ aparat pemerintah di wilayah kecamatan Abeli yang belum pernah mengikuti diklat teknis profesional. Kondisi ini menunjukkan bahwa dilihat dari sisi keikutsertaan aparat pemerintah di wilayah kecamatan Abeli dalam diklat teknis profesional, maka dapat dikatakan bahwa kualitas sumber daya aprat di wilayah penelitain ini tergolong tinggi.

Selanutnya, manfaat Pendidikan Formal dan Pengalaman Kerja Terhadap Peningkatan Kemampuan Kerja Aparat Di Kecamatan Abeli Kota Kendari, Tahun. 2009 jelaskan pada Tabel 3. 
Tabel 3

Manfaat Pendidikan Formal dan Pengalaman Kerja Terhadap Peningkatan Kemampuan Kerja Aparat Di Kecamatan Abeli Kota Kendari, Tahun. 2009

\begin{tabular}{|c|c|c|c|c|c|}
\hline \multirow{3}{*}{ No } & \multicolumn{5}{|c|}{ Pandangan Responden } \\
\hline & \multirow[t]{2}{*}{ Kategori } & \multicolumn{2}{|c|}{ Pendidikan Formal } & \multicolumn{2}{|c|}{ Pengalaman Kerja } \\
\hline & & Frekuensi & $\%$ & Frekuensi & $\%$ \\
\hline l & Sangat Menunjang & 52 & 80,00 & 48 & 73,84 \\
\hline 2 & Menunjang & 8 & 12,30 & 12 & 18,46 \\
\hline 3 & Ragu-Ragu & 5 & 07,70 & 5 & 7,70 \\
\hline 4 & Tidak Menunjang & 0 & 0 & 0 & 0 \\
\hline 5 & Sangat Tdk Menunjang & 0 & 0 & 0 & 0 \\
\hline & Jumlah & 65 & 100 & 65 & 100 \\
\hline
\end{tabular}

Sumber : Diolah dari data primer, 2009.

Pada tabel 3, mayoritas responden berpandangan yang sama dalam menilai tentang manfaat pendidikan formal dan manfaat pengalaman kerja dalam menunjang kemampuan kerja pegawai di wilayah Keamatan Abeli. Sebanyak 80\% responden menlai bahwa pendidikan formal sangat bermanfaat dalam menunjang kemampua kerja mereka. Selebihnya, 12,30\% menyatakan menunjang dan sebanyak 7,70\% menyatakan ragu-ragu. Dengan demikian tidak ada responden yang menyatakan bahwa pendidikan formal tidak menunjang kemampuan kerja mereka. Demikian halnya dengan faktor pengalaman kerja, sebanyak 73,84\% menilai bahwa pengalaman kerja sangat menunjang kemampuan kerja mereka. Selebihnya, 18,64\% menyatakan menunjang dan 7,70 yang masih ragu-ragu. Sebaran jawaban responden yang dikemukakan di atas, jelaslah kiranya bahwa baik pendidikan formal yang dimiliki oleh pegawai pada Kantor Kecamatan Abeli, dan pengalaman kerjanya, hampir seluruh responden bahwa hal itu sangat menunjang kemampuan kerja jika sesuai dengan bidang tugas dan fungsi mereka masing-masing. Dengan temuan seperti ini maka tidak ada alasan bagi para pimpinan organisasi pemerintahan untuk tidak menetapkan kebijakan pengembangan sumber daya aparatur melalui program pendidikan formal. Artinya perlu dilakkan upaya pengembangan staf dengan menyediakan fasilitas biaya dan izin belajar bagi staf secara terpeogram setiap tahunnya. Hal ini sejalan dengan pandangan Notoatmodjo, (1993:24) bahwa betapa pun canggihnya peralatan tanpa ditunjang oleh kemampuan aparat, maka pekerjaan tidak akan mencapai tingkat efektivitas yang diinginkan.

Terkait dengan faktor kemampuan kerja pegawai di setiap organisasi pemerintahan, maka salah satu hal yang perlu dipertimbangkan adalah kesesuaian antara tugas yang diberikan kepada seseorang staf dengan latar belakang pendidikan formal yang dimilikinya. Hasil penelitian in menunjukkan kondisi kesesuaian antara tugas dan latar belakang pendidikan formal pegawai di wilayah Kecamatan Abeli sebagaimana diperlihatkan pada tabel 4: 


JCunal publiuho is licensed under a Creative Commons Attribution 4.0 International License, which permits
unrestricted use, distribution, and reproduction in any medium, provided the original work is properly cited.

Tabel 4

Kesesuaian antara Latar Belakang Pendidikan Formalnya dan Pengalaman Kerjanya

Dengan Tupoksinya pada Kantor Pemerintahan Di Kecamatan Abeli, 2009

\begin{tabular}{|c|l|c|c|c|c|}
\hline \multirow{2}{*}{ No. } & \multicolumn{2}{|c|}{ Kategori } & \multicolumn{2}{c|}{ Pengalaman Kerja } & \multicolumn{2}{c|}{ Pendidikan Formal } \\
\cline { 3 - 6 } & & Frekuensi & $\%$ & Frekuensi & $\%$ \\
\hline 1 & Sangat Sesuai & 13 & 15,00 & 15 & 23,00 \\
\hline 2 & Sesuai & 15 & 25,07 & 16 & 24,62 \\
\hline 3 & Ragu-Ragu & 10 & 15,38 & 7 & 10,76 \\
\hline 4 & Tidak Sesuai & 24 & 37,92 & 20 & 30,86 \\
\hline 5 & Sangat Tidak Sesuai & 03 & 6,63 & 7 & 10,76 \\
\hline \multicolumn{2}{|l|}{ Jumlah } & 65 & 100,00 & 65 & 100,00 \\
\hline
\end{tabular}

Sumber : Diolah dari data primer, 2009.

Pada tabel 4, dapat diinterpretasi bahwa mayoritas (30,86\%) responden memberi jawaban kategori ketiga bahwa latar belakang pendidikan forlmal yang mereka miliki tidak sesuai dengan tugas dan fungsi yang dibebankan kepadanya, bahkan terdapat $10,76 \%$ responden yang merasakan sangat tidak sesuai antara latar belakang pendidikan formalnya dengan tugas dan fungsi yang diembannya. Demikian pula dengan penilaian responden tentang kesesuaian antara pengalaman kerja yang dimilikinya dengan tugas dan fungsi yang dibebankan kepadanya, ternyata mayoritas $(37,92 \%)$ memberikan jawaban pada kategori ketiga, bahwa pengalaman kerjanya tidak sesuai dengan bidang tugas yang diberikan kepadanya. Bahkan terdapat $3,63 \%$ responden yang menyatakan sangat tidak sesuai antara pengalaman kerjanya dengan tugas dan fungsinya. Data ini menunjukkan bahwa proses penempatan dan promosi pegawai dalam jajaran birokrasi pemerintahan kota Kendari secara umum dan khususnya kecamatan Abeli, masih menggunakan pendekatan nepotisme. Kondisi ini semakin memperburuk citra dan kinerja organisasi pemerintahan di mata publik. Hal ini sejalan dengan hasil wawancara penulis terhadap seorang informan bahwa :Sampai saat ini pihak pemerintah Kota Kendari belum memanfaatkan Daftar Penilaian Pelaksanaan Pekerjaan (DP3) dalam melakukan promosi jabatan. Demikian pula dalam penempatan sesorang belum mempertimbangkan latar belakang pendidikan dan pengalaman pegawai (Wawancara 6 November 2009).

Uraian di atas sejalan dengan pandangan Rasyid (1997:128) yang pada prinsipnya menyatakan bahwa kemampuan kerja pegawai atau staf dapat dioptimalkan melalui pendekatan pendidikan dan pengalaman kerja. Artinya latar belakang pendidikan dan pengalaman kerja perlu dipertimbangkan ketika seorang pimpinan mempromosikan atau pun menempatkan staf pada suatu jabatan tertentu.

Oleh karena itu, seharusnya pemerintah Kota Kendari merubah pola penempatan dan promosi pegawai melalui pertimbangan kemampuan pegawai yang didasarkan pada latar belakan pendidikan formal dan latar belakang pengalaman kerja pegawai yang bersangkutan. Hal ini perlu didasari kesadaran pemerintah untuk meningggalkan pola lama yang merugikan organisasi dan merugikan kualitas pelayanan publik yang diakibatkan oleh pola promosi dan penempatan yang didasarkan atas pendekatan nepotisme.

Selain pendidikan formal dan pengalaman kerja sebagai penentu kemampuan aparat dalam pelaksanaan tugas dan fungsinya, juga ditentukan oleh diklat teknis dan profesional yang diikuti oleh aparat. Terkait dengan itu, pada bagian berikut ini dapat dilihat tanggapan responden aparat di wilayah Kecamatan Abeli tentang bagaimana pengaruh diklat yang pernah diikutinya terhadap kemampuan kerjanya seperti sajian tabel 5 di bawah ini: 
Vol.2 No.1. April 2018. pp.38-50.Copyright@2018 PUBLICUHO Faculty of Social and Political Sciences Halu Oleo University, Kendari, Southeast Sulawesi, Indonesia.e-ISSN: 2621-1351. Open Access at:

Jounal publiuho is licensed under a Creative Commons Attribution 4.0 International License, which permits unrestricted use, distribution, and reproduction in any medium, provided the original work is properly cited.

\section{Tabel 5}

Pengaruh Diklat Teknis Profesional yang Pernah Diikuti Terhadap Kemampuan Kerjanya dalam Penyelenggaraan Pemerintahan di Kecamatan Abeli Kota Kendari

\begin{tabular}{|l|l|c|c|}
\hline No. & \multicolumn{1}{|c|}{ Kategori } & Frekuensi & $\%$ \\
\hline 1 & Sangat menunjang & 10 & 15,38 \\
\hline 2 & Menunjang & 12 & 18,46 \\
\hline 3 & Ragu-Ragu & 19 & 29,23 \\
\hline 4 & Tidak Menunjang & 20 & 30,77 \\
\hline 5 & Sangat Tidak Menunjang & 4 & 6,16 \\
\hline & Jumlah & 65 & 100,00 \\
\hline
\end{tabular}

Sumber : Diolah dari data primer, 2009.

Pada tabel 5 menunjukkan bahwa mayoritas (30,77\%) responden menilai bahwa diklat teknis profesional yang pernah diikutinya tidak menunjang kemampuan kerjanya pada unit kerja penempatannya. Bahkan sebanyak 6,16\% responden menilai sangat tidak menunjang dan 29,23\% menyatakan ragu-ragu. Ini berarti bahwa hanya $33,48 \%$ responden yang menilai bahwa diklat yang pernah diikutinya menunjang kempuan kerjanya. Makna dari sebaran data tersebut menunjukkan bahwa pemberian materi diklat selama ini tidak efektif. Ketidakefektifan itu dapat disebabkan oleh dua faktor. Faktor. Pertama adalah materi diklat tidak sesuai dengan bidang tugas dan fungsi para peserta diklat. Kedua, penempatan pegawai dalam promosi-promosi dan mutasi, tidak mempertimbangkan latar belakang kemampuan profesional yang dimilikinya.

Demikian halnya dengan diklat penjenjangan yang dikenal dengan SESPIM (Sekolah Staf Pimpinan) Tingkat I, II, III dan IV yang diperuntukkan bagi pejabat eselon I, II, III dan IV, ternyata menurut penilaian responden yang pernah mengikuti diklat penjenjangan tersebut, terlihat bervariasi sebagamana disajikan dalam tabel 12 sebagai berikut:

Tabel 6

Pengaruh Diklat Penjenjangan yang Pernah Di ikuti Terhadap Kemampuan Kerjanya dalam Penyelenggaraan Pemerintahan di Kecamatan Abeli Kota Kendari

\begin{tabular}{|l|l|c|c|}
\hline No. & \multicolumn{1}{|c|}{ Kategori } & Frekuensi & $\%$ \\
\hline 1 & Sangat menunjang & 0 & 00,00 \\
\hline 2 & Menunjang & 12 & 80,00 \\
\hline 3 & Ragu-Ragu & 3 & 20,00 \\
\hline 4 & Tidak Menunjang & 0 & 00.00 \\
\hline 5 & Sangat Tidak Menunjang & 0 & 00,00 \\
\hline \multicolumn{2}{|l|}{ Jumlah } & 15 & 100,00 \\
\hline
\end{tabular}

Sumber : Diolah dari data primer, 2009.

Pada tabel 6, pengaruh diklat penjenjangan terhadap kemampuan kerja pegawai pada kantor pemerintahan di Kecamatan Abeli menunjukkan penilaian yang positif dari responden yang pernah mengikuti diklat penjenjangan. Dari 15 responden yang pernah mengkuti diklat penjenjangan ternyata 80\% di antaranya menilai bahwa diklat penjenjangan yang pernah diikutinya menunjang tugas dan fungsinya pada kantor pemerintahan 
di wilayah kecamatan Abeli. Sedangkan sisanya (20\%) masih menjawab rag-ragu. Kondisi ini dapat dimaknai bahwa materi diklat penjenjangan relatif relevan dengan tugas pokok dan fungsi yang dipercayakan kepadanya. Hal ini beralasan karena biasanya pegawai yang dipersiapkan menduduki jabatan eselon terlebih dahulu diikutkan dalam diklat SESPIM.

\section{Pengaruh Pengalaman Kerja Aparat Terhadap Kualitas Pelayanan Publik di Wilayah Kecamatan Abeli Kota Kendari}

Pengaruh pengalaman kerja aparat terhadap kualitas pelayanan publik di wilayah Kecamatan Abeli, juga menunjukkan kondisi yang sama dengan pengaruh dimensi-dimensi lainnya dalam arti belum sesuai dengan apa yang seharusnya. Secara teoretis dapat dipahami bahwa kematangan pengalaman seseorang akan mempengaruhi kemampuan kerjanya. Hal ini memperlihatkan perbedaan kematangan berpikir dan kematngan emosional antara yang berpengalaman dan yang tidak berpengalaman dalam suatu bidang tertentu. Akumulasi dari kematangan pengalaman itu selanjutnya terakumulasi pula mempengaruhi kemampuan kerja.

Temuan penelitian ini menggambarkan bahwa pengalaman kerja tidak selamanya bermanfaat untuk menunjang kemampuan kerja seseorang. Data yang terkumpul menunjukkan bahwa lebih dari separu $(52,38 \%)$ responden menyatakan bahwa pengalaman kerja yang diperolehnya selama menjalani karier sebagai aparat pemerintah di lingkungan pemerintahan Kota Kendari, dirasakan sebagai faktor yang sangat menunjang kemampuan profesionalnya. Namun demikian realitas menunjukkan bahwa pengalaman kerja yang dimiliki oleh mamaoritas $(52,38 \%)$ responden, ternyata kurang bermanfaat karena penempatannya tidak relevan dengan pengalaman kerjanya selama ini.

Secara umum, faktor pengalaman kerja yang dimiliki oleh aparat pemerintah di wilayah kecamatan Abeli, kurang menunjang kemampuan kerjanya. Kondisi tersebut disebabkan oleh penempatan aparat yang tidak sesuai dengan bidang keahlian yang ditekuninya selama ini. Penempatan yang dimaksud terdiri dari dua macam. Pertama, penempatan sejak awal bertugas di wilayah penelitian ini, yaitu wilayah Kecamatan Abeli, Kedua, penempatan dalam arti hasil mutasi/rotasi yang dilakukan oleh pemerintah Kota Kendari selama pegawai itu bertugas di wilayah Kecamatan Abeli. Terdapat kesesuaian antara pengalaman kerja tersebut, dinilai pada saat penelitian ini dilakukan, yang pada dasarnya menunjukkan bahwa pengalaman kerja aparat di wilayah Kecamatan Abeli, tidak menunjang kemamuan kerjanya dalam pelaksanaan tugas pelayanan publik di daerah penelitian ini.

\section{KESIMPULAN}

Berdasarkan hasil penelitian dan uraian dalam pembahasan, maka dapat disimpulkan sebagai berikut :

1. Kondisi kemampuan aparat pemerintah dalam pelayanan publik di wilayah Kecamatan Abeli Kota Kendari dapat digambarkan melalui 3 (tiga) dimensi pokok kemampuan aparat yang mempunyai pengaruh terhadap kualitas pelayanan publik, sebagai berikut:

a. Dilihat dari faktor pendidikan formal aparat pemerintah di wilayah Kecamatan Abeli, tergolong masih berada pada kategori rendah. Hal ini dibuktikan dengan data aparat yang berpendidikan Sl ke atas sangat rendah jumlahnya, atau hanya 29,23\%. Ini berarti masih didominasi oleh aparat yang berpendidikan SMTA kebawah yang jumlahnya sebanyak 70,87\%.

b. Dilihat dari faktor pendidikan dan pelatihan (Diklat) teknis profesional, ternyata jumlah aparat yang telah mengikuti diklat teknis profesional tergolong tinggi. Sisa 6,15\% aparat yang belum pernah mengikuti diklat teknis profesional. Namun demikian, lebih dari separu atau $66,16 \%$ aparat yang 
Jounal publiuho is licensed under a Creative Commons Attribution 4.0 International License, which permits unrestricted use, distribution, and reproduction in any medium, provided the original work is properly cited.

pernah mengikuti diklat teknis profesional menyatakan tidak menunjang kemampuan kerjanya disebabkan oleh kebijakan penunjukan peserta diklat tidak disesuaikan dengan bidang kerjanya.

c. Secara umum, pengalaman kerja aparat selama menjalani karier sebagai aparat pemerintah Kota Kendari, sangat menunjang kemampuan profesionalnya. Namun demikian, pengalaman tersebut kurang bermanfaat karena penempatannya tidak relevan dengan pengalaman kerjanya.

2. Pengaruh kemampuan aparat pemerintah terhadap kualitas pelayanan publik di wilayah Kecamatan Abeli Kota Kendari, secara umum tergolong rendah. Hal tersebut dapat ditelusuri melalui tiga faktor penting yang menentukan tingkat kemampuan aparat, sebagai berikut :

a. Dari sisi tingkat pendidikan formal aparat menunjukkan pengaruh yang tergolong rendah. Hal tersebut sesuai dengan temuan yang menunjukkan bahwa hanya sebagian kecil $(29,23 \%)$ aparat yang berpendidikan minimal Sl ke atas. Jumlah ini jauh berada di bawah rata-rata nasional yaitu $35 \%$ sampai dengan $40 \%$.

b. Dari sisi diklat teknis profesional yang pernah diikuti oleh aparat pemerintah di wilayah Kecamatan Abeli, ternyata menunjukkan kurang berpengaruh terhadap kemampuan kerja pada bidang tugasnya. Kurangnya pengaruh itu, antara lain disebabkan oleh kebijakan pimpinan dalam penunjukan peserta diklat yang tidak didasarkan pada kesesuaian antara jenis diklat yang diselenggarakan dengan bidang tugas aparat yang ditunjuk sebagai peserta diklat. Demikian pula mutasi dan rotasi aparat yang terlampau sering dilakukan dengan tidak memperhitungkan kesesuaian antara latar belakang keahlian aparat dengan bidang tugas yang baru.

c. Dari sisi pengalaman kerja aparat di wilayah Kecamatan Abeli, secara umum sangat berpengaruh terhadap kemampuan kerjanya. Namun kenyataan kurang menunjang kemampuan kerja karena penempatannya tidak relevan dengan pengalaman kerja yang diperolehya selama ini.

\section{REKOMENDASI}

1. Untuk meningkatkan kemampuan kerja aparat pemerintah di wilayah Kecamatan Abeli dalam upaya peningkatan kualitas pelayanan publik, maka seyogyanya pihak pemerintah Kota Kendari menetapkan kebijakan peningkatan pendidikan formal aparat di wilayah Kecamatan Abeli, dengan cara membuat rencana jangka pendek, jangka menengah dan jangka penjang disertai penyediaan anggaran yang cukup.

2. Dalam penunjukan aparat yang diikutsertakan dalam penyelenggaraan diklat teknis profesional tertentu, hendaknya disesuaikan antara jenis/bidang diklat yang diselenggarakan dengan bidang tugas peserta diklat. Dengan demikian hasil diklat benar-benar bermanfaat dalam menjunjang kemampuan kerja aparat pada bidang tugasnya.

3. Agar pengalaman kerja yang dimiliki aparat pemerintah di wilayah Kecamatan Abeli bermanfaat dalam menunjang kemampuan kerjanya, maka semestinya penempatan aparat pada bidang tugas tertentu disesuaikan dengan pengalaman kerjanya

4. Mutasi atau rotasi aparat pemerintah yang dilakukan oleh pemerintah Kota Kendari secara umum dan pemerintah Kecamatan Abeli secara khusus, hendaknya memperhatikan relevansi dan konsistensi antara latar belakang pendidikan, ketrampilan dan pengalaman kerja yang dimiliki aparat dengan penempatannya pada bidang tugas yang baru. 


(C) Jounal publiuho is licensed under a Creative Commons Attribution 4.0 International License, which permits
unrestricted use, distribution, and reproduction in any medium, provided the original work is properly cited.

\section{DAFTAR PUSTAKA}

Bernaddin. 1995. Human Resource Management. Singapore: McGraw Hill. Inc.

Hasibuan.2000. Manajemen Sumber Daya Manusia. Jakarta: Gunung Agung.

Moenir, 1992. Manajemen Pelayanan Umum di Indonesia. Jakarta: Bumi Aksara.

Noto Atmodjo, Soekidjo. 1998. Pengembangan Sumber Daya Manusia. Jakarta: Rineka Cipta.

Rasyid, M. Ruaas.1996. Makana Pemerintahan: Tinjauan dari Segi Etika dan Kepemimpinan. Jakarta: PT Yarsif Watampone.

Siagian Sondang P. 1997. Manajemen Sumber Daya Manusia. Jakarta: Bina Aksara. 1994. Patologi Administrasi, Analisis, Identifikasi dan Terapinya. Jakarta: Ghalia Indonesia.

Simbolon. 1998. Fungsi-Fungsi Pemerintahan. Jakarta: Diklat Depdagri.

Sjahrir, 1998. Kebijaksanaan Negara : Konsistensi dan Implementasi. Jakarta: LP3ES.

1986. Pelayanan dan Jasa-Jasa Publik: Telaah Ekonomi dan Implikasi Politik. Prisma No.12 Desember 1986. Jakarta: LP3ES.

Sumarjono.1989. Kepemimpinan. Malang: sangkakala.

Syafiie, Kencana Inul. 1999. Sistem Administrasi Negara Republik Indonesia (SANRI). Bandung: Bumi Aksara.

Tjiptono. 1996. Manajemen Jasa. Yogyakarta: Andi Press. 